\title{
New Thiophene-Phenylene-Thiophene Acceptor Random Conjugated Copolymers for Optoelectronic Applications
}

\author{
JUNG-HSUN TSAI, ${ }^{1}$ CHU-CHEN CHUEH, ${ }^{1}$ WEN-CHANG CHEN, ${ }^{1,2}$ CHAO-YING YU, ${ }^{3}$ GUE-WUU HWANG, ${ }^{3}$ \\ CHING TING, ${ }^{3}$ EN-CHEN CHEN, ${ }^{4}$ HSIN-FEI MENG ${ }^{5}$ \\ ${ }^{1}$ Department of Chemical Engineering, National Taiwan University, Taipei 106, Taiwan, Republic of China \\ ${ }^{2}$ Institute of Polymer Science and Engineering, National Taiwan University, Taipei 106, Taiwan, Republic of China \\ ${ }^{3}$ Materials and Chemical Laboratories, Industrial Technology Research Institute, Hsinchu, Taiwan 300, Republic of China \\ ${ }^{4}$ Department of Electrical Engineering, National Tsing Hua University, Hsinchu 300, Taiwan, Republic of China \\ ${ }^{5}$ Institute of Physics, National Chiao Tung University, Hsinchu 300, Taiwan, Republic of China
}

Received 3 February 2010; accepted 28 February 2010

DOI: $10.1002 /$ pola.24002

Published online in Wiley InterScience (www.interscience.wiley.com).

ABSTRACT: New low band gap thiophene-phenylene-thiophene (TPT)-based donor-acceptor-donor random copolymers were synthesized for optoelectronic device applications by a palladium-catalyzed Stille coupling reaction under microwave heating. The acceptors included 2,3-bis(4-(2-ethylhexyloxy)phenyl)5,8-bis[5'-bromo-dithien-2-yl-quinoxalines] (DTQ) and 3,6-bis(5bromothiophen-2-yl)-2,5-bis(2-ethyl-hexyl)-pyrrolo[3,4-c]-pyrrole1,4-dione (DPP). The prepared random copolymers were named as PTPTDTQ $_{0.55}$, PTPTDTQ $\mathbf{0}_{0.34}$ DPP $_{\mathbf{0 . 1 4}}$, and PTPTDTQ $_{0.26}$ DPP $_{0.34}$ depending on the copolymer ratio. The optical band gaps $\left(E_{g}^{\text {opt }}\right)$ of PTPTDTQ ${ }_{0.55}$, PTPTDTQ ${ }_{0.34}$ DPP $_{0.14}$, and PTPTDTQ ${ }_{0.26}$ DPP $_{0.34}$ were $1.74,1.56$, and $1.48 \mathrm{eV}$, respectively. The hole mobility obtained from the field-effect transistor devices prepared from PTPTDTQ $_{0.55}$, PTPTDTQ $_{0.34}$ DPP $_{\text {0.14 }}$, and PTPTDTQ $_{0.26}$ DPP $_{0.34}$ were $2.2 \times 10^{-3}, 2.4 \times 10^{-3}$, and $4.7 \times 10^{-3} \mathrm{~cm}^{2} \mathrm{~V}^{-1} \mathrm{~s}^{-1}$, respectively, with the on-off ratios of $4.0 \times 10^{4}, 4.0 \times 10^{4}$, and $5.3 \times 10^{4}$. It suggested that the significant intramolecular charge transfer between the TPT and acceptor led to the band gap reduction and hole mobility enhancement. Polymer solar cells of these TPT-based copolymers blended with 1-(3-methoxycarbonyl)propyl-1-phenyl-[6,6]-C-71 (PC $\left.\mathrm{P}_{71} \mathrm{BM}\right)$ under illumination of AM $1.5 \mathrm{G}\left(100 \mathrm{~mW} \mathrm{~cm}^{-2}\right)$ solar simulator exhibited a power conversion efficiency (PCE) as high as $3.71 \%$. Besides, the near-infrared photodetector device prepared from PTPTDTQ $_{0.26}$ DPP $_{\mathbf{0 . 3 4}}$ showed a high external quantum efficiency exceeding $32 \%$ at $700 \mathrm{~nm}$ (under $-3 \mathrm{~V}$ bias) and fast-speed response. This study suggests that the prepared TPT-based donoracceptor random copolymers exhibited promising and versatile applications on optoelectronic devices. (c) 2010 Wiley Periodicals, Inc. J Polym Sci Part A: Polym Chem 48: 2351-2360, 2010

KEYWORDS: conjugated polymers; copolymerization; donoracceptor; FET; photodetectors; photovoltaics; polycondensation; small band gap
INTRODUCTION Donor-acceptor (D-A) conjugated copolymers have attracted extensive research interest because of their tunable electronic and optoelectronic properties through intramolecular charge transfer (ICT). ${ }^{1,2}$ Various device applications have been explored for such conjugated copolymers, including light emitting diodes (LEDs), ${ }^{3-9}$ photovoltaic cells, ${ }^{10-33}$ field-effect transistors (FETs), ${ }^{34-42}$ and photodetectors (PDs). ${ }^{43,44}$ Among the D-A alternating conjugated polymers, the electron-donating moieties of fluorene, ${ }^{3-7,23}$ thiophene, ${ }^{30,31,36-40,45-47}$ dialkoxylphenylene, ${ }^{38,48,49}$ carbazole $^{50-53}$ indolocarbazole, ${ }^{16,17}$ and cyclopentadithiophene $\mathrm{e}^{28,29,33}$ in combination with various electron-withdrawing acceptor or donor-acceptor-donor (D-A-D) blocks have recently been reported.

Thiophene-phenylene-thiophene (TPT)-based materials have emerged as superior building block for the construction of conjugated polymers. The coplanar chromophore, featuring embedded heteroarenes as constituents of coplanar conjugated backbones, may exhibit a strong intermolecular $\pi-\pi$ interaction, and thus enhances the degree of $\pi$-conjugation. ${ }^{13-15}$ The use of tetrahexylaryl groups, positioned as peripheral substituents of the TPT units, tailors the intermolecular interaction between the polymer chains to provide improved morphologies and processability (Scheme 1). In our previous works, copolymers of TPT unit incorporated with thiophene or bithiophene exhibited a hole mobility up to $3 \times 10^{-3} \mathrm{~cm}^{2} \mathrm{~V}^{-1} \mathrm{~s}^{-1}$ as well as a promising solar cell efficiency of $3.3 \%{ }^{14}$ Recently, a series of low band gap TPT-based copolymers using D-A strategy were developed to extend the absorption spectrum and the solar cell efficiency of more than $4 \%{ }^{15}$

The introduction of D-A-D building blocks incorporated into the polymer main chain not only facilitates a stronger ICT

Additional Supporting Information may be found in the online version of this article. Correspondence to: W.-C. Chen (E-mail: chenwc@ntu.edu.tw) or C. Ting (E-mail: cting@itri.org.tw)

Journal of Polymer Science: Part A: Polymer Chemistry, Vol. 48, 2351-2360 (2010) (c) 2010 Wiley Periodicals, Inc. 


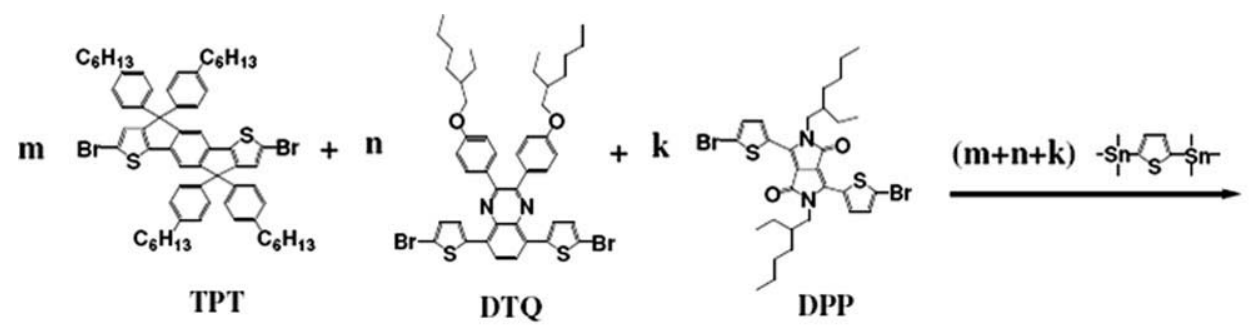

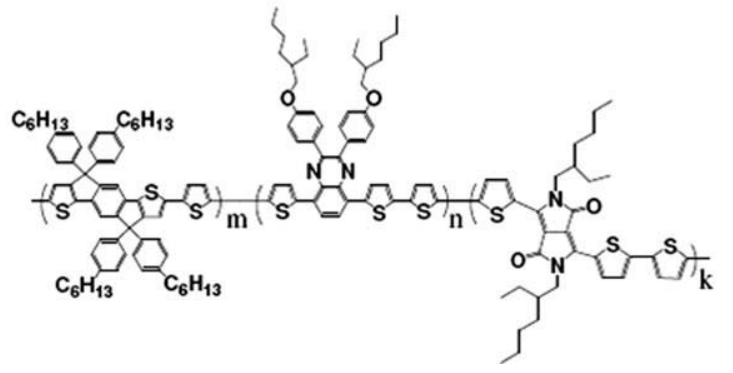

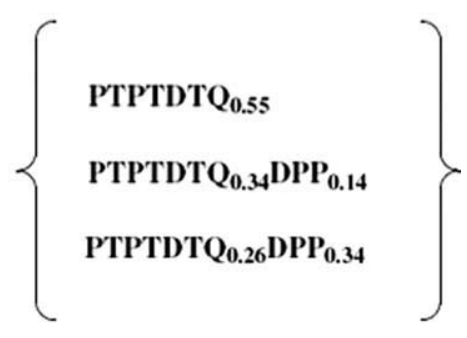

SCHEME 1 Reaction scheme on preparing the TPT-based donoracceptor random copolymers. but also boosts the coplanar conformation to further lower the band gap. ${ }^{23,38,54}$ Our goal in this study is to construct TPT-based D-A-D copolymers with different composition of the acceptor blocks (DTQ and DPP). Also, such polymer systems are expected to have a relatively small band gap and could be used to explore the device applications of FETs, photovoltaic cells, and near-infrared photodetectors (NIRPDs). Here, we report the synthesis, properties, and optoelectronic device applications of new TPT-based conjugated copolymers, including PTPTDTQ ${ }_{0.55}$, PTPTDTQ $_{\mathbf{0 . 3 4}_{4}} \mathbf{D P P}_{\mathbf{0 . 1 4}}$, and PTPTDTQ $_{\mathbf{0 . 2 6}_{6}} \mathbf{D P P}_{\mathbf{0 . 3 4}}$. These random polymers consisted of TPT, 2,5-bis(trimethylstannyl)thiophene, and different acceptor compositions of DTQ and DPP were synthesized by a palladium-catalyzed Stille coupling reaction under microwave heating, as shown in Scheme 1. The field-effect carrier mobility was obtained from the bottom gate thin film transistor (TFT) devices and correlated with the polymer structures. Polymer solar cell devices were fabricated by spin-coating polymer blend of TPT-based copolymers/ $\mathrm{PC}_{71} \mathrm{BM}$, sandwiched between a transparent anode (ITO) and cathodes $(\mathrm{Ca} / \mathrm{Al})$. Also, the polymer blend of PTPTDTQ $_{0.26}$ DPP $_{\mathbf{0 . 3 4}} / \mathrm{PC}_{71} \mathrm{BM}$ was explored for near-infrared organic PDs applications, which requires polymers with a low band gap and high carrier mobility. ${ }^{43,44}$ Our experimental results suggested the TPT-based D-A-D conjugated copolymers showed versatile optoelectronic applications.

\section{EXPERIMENTAL}

\section{Materials}

Tri(o-tolyl)phosphine, tris(dibenzylideneacetone)dipalladium (0), trimethyl(thiophen-2-yl)stannane, and bromothiophene were purchased from Aldrich (Aldrich, MO) and used without further purification. Ultra-anhydrous solvents and common organic solvents were purchased from Tedia, Merck, and J.T. Baker. The following donors or acceptors were prepared according to literature procedures: (TPT, ${ }^{13-15} 2,5$-bis (trimethylstannyl)thiophene, ${ }^{14}$ 2,3-bis(4-(2-ethylhexyloxy)- phenyl)-5,8-bis [5'-bromo-dithien-2-yl-quinoxalines] (DTQ), ${ }^{18}$ and 3,6-bis(5-bromothiophen-2-yl)-2,5-bis(2-ethylhexyl)pyrrolo[3,4-c]-pyrrole-1,4-dione (DPP). ${ }^{55,56}$ 1-(3-Methoxycarbonyl)propyl-1-phenyl-[6,6]-C-71 $\quad\left(\mathrm{PC}_{71} \mathrm{BM}\right)$ was purchased from Solenne (Groningen, The Netherlands) for solar cell device application.

\section{General Procedures of Polymerization}

The general procedure of synthesizing TPT-acceptor random copolymers is shown in Scheme 1. Donor monomers (TPT and 2,5-bis(trimethylstannyl)thiophene), donor-acceptor-donor blocks (DTQ and DPP), tri(o-tolyl)phosphine (16 mol \% with respect to ditin monomer), and tris(dibenzylideneacetone) dipalladium (0) (2 mol \% with respect to ditin monomer) were dissolved in chlorobenzene and these copolymers were synthesized by $\operatorname{Pd}(0)$-catalyzed Stille coupling polymerization under microwave heating. After end-capped with trimethyl(thiophen2-yl)stannane and bromothiophene (both 1.1 equiv. with respect to ditin monomer), the mixture was cooled and poured into hexane. The precipitated material was dissolved into a small amount of $\mathrm{CHCl}_{3}$ and then re-precipitated into methanol to afford a crude polymer. The crude polymer was washed for $24 \mathrm{~h}$ with acetone to remove oligomers and catalyst residues.

\section{Synthesis of PTPTDTQ}

A total of $532.6 \mathrm{mg}(0.50 \mathrm{mmol})$ of the TPT, $430.4 \mathrm{mg}(0.50$ mmol) of the DTQ, $410.0 \mathrm{mg}$ of the 2,5-bis(trimethylstannyl)thiophene $(1.0 \mathrm{mmol})$, and $15 \mathrm{~mL}$ of chlorobenzene were used to afford a black solid (Yield: 55\%).

${ }^{1} \mathrm{H} \mathrm{NMR}\left(\mathrm{CDCl}_{3}\right), \delta(\mathrm{ppm}): 8.15-6.81(\mathrm{~m}, \mathrm{br}, \mathrm{Ar}-\mathrm{H}), 3.90(\mathrm{br}$, $\mathrm{Ar}-\mathrm{OCH}_{2}$ ), 2.57 (br, $\left.\mathrm{Ar}-\mathrm{CH}_{2}\right), 1.85-1.10$ (m, br, $-\mathrm{CH}_{2}$, $-\mathrm{CH}), 1.10-0.65\left(\mathrm{~m}, \mathrm{br},-\mathrm{CH}_{3}\right)$. Anal. Calcd. for $\left[\left(\mathrm{C}_{68} \mathrm{H}_{74} \mathrm{~S}_{3}\right)_{1}\right.$ $\left.+\left(\mathrm{C}_{48} \mathrm{H}_{50} \mathrm{~N}_{2} \mathrm{~S}_{3}\right)_{0.55}\right]: \mathrm{C}, 79.97 ; \mathrm{H}, 7.22 ; \mathrm{N}, 1.08 ; \mathrm{S}, 10.50$. Found: C, 77.24; H, 6.99; N, 1.02; S, 10.84. Weight-averaged molecular weight $\left(M_{\mathrm{w}}\right)$ and polydispersity index (PDI) estimated from GPC are 76,000 and 1.97 , respectively. 
Synthesis of PTPTDTQ ${ }_{0.34}$ DPP $_{\mathbf{0 . 1 4}}$

A total of $266.3 \mathrm{mg}(0.25 \mathrm{mmol})$ of the TPT, $161.4 \mathrm{mg}(0.19$ $\mathrm{mmol})$ of the DTQ, $42.7 \mathrm{mg}(0.06 \mathrm{mmol})$ of the DPP, 204.9 $\mathrm{mg}$ of the 2,5-bis(trimethylstannyl)thiophene $(0.5 \mathrm{mmol})$, and $10 \mathrm{~mL}$ of chlorobenzene were used to afford a black solid (Yield: 60\%).

${ }^{1} \mathrm{H}$ NMR $\left(\mathrm{CDCl}_{3}\right), \delta$ (ppm): 9.01-6.75 (m, br, Ar- $\left.\mathrm{H}\right), 4.30-$ 3.72 (br, $\mathrm{Ar}-\mathrm{OCH}_{2}, \mathrm{~N}-\mathrm{CH}_{2}$ ), 2.57 (br, $\mathrm{Ar}-\mathrm{CH}_{2}$ ), 2.05-1.10 (m, br, $\left.-\mathrm{CH}_{2},-\mathrm{CH}\right), 1.10-0.70$ (m, br, $-\mathrm{CH}_{3}$ ). Anal. Calcd. for $\left[\left(\mathrm{C}_{68} \mathrm{H}_{74} \mathrm{~S}_{3}\right)_{1}+\left(\mathrm{C}_{48} \mathrm{H}_{50} \mathrm{~N}_{2} \mathrm{~S}_{3}\right)_{0.34}+\left(\mathrm{C}_{34} \mathrm{H}_{40} \mathrm{~N}_{2} \mathrm{~S}_{3}\right)_{0.14}\right]: \mathrm{C}$, 79.94; H, 7.28; N, 1.01; S, 10.63. Found: C, 78.00; H, 7.18; N, 1.26; S, 10.75. Weight-averaged $M_{\mathrm{w}}$ and PDI estimated from GPC are 68,000 and 2.49, respectively.

\section{Synthesis of PTPTDTQ ${ }_{0.26} \mathrm{DPP}_{\mathbf{0 . 3 4}}$}

A total of $319.6 \mathrm{mg}(0.3 \mathrm{mmol})$ of the TPT, $129.1 \mathrm{mg}(0.15$ $\mathrm{mmol})$ of the DTQ, $102.4 \mathrm{mg}(0.15 \mathrm{mmol})$ of the DPP, 245.9 $\mathrm{mg}$ of the 2,5-bis(trimethylstannyl)thiophene $(0.6 \mathrm{mmol})$, and $10 \mathrm{~mL}$ of chlorobenzene were used to afford a black solid (Yield: 58\%).

${ }^{1} \mathrm{H}$ NMR $\left(\mathrm{CDCl}_{3}\right), \delta(\mathrm{ppm}): 9.05-6.80(\mathrm{~m}, \mathrm{br}, \mathrm{Ar}-\mathrm{H}), 4.30-$ 3.74 (br, $\mathrm{Ar}-\mathrm{OCH}_{2}, \mathrm{~N}-\mathrm{CH}_{2}$ ), 2.57 (br, $\mathrm{Ar}-\mathrm{CH}_{2}$ ), 2.10-1.12 (m, br, $\left.-\mathrm{CH}_{2},-\mathrm{CH}\right), 1.12-0.70\left(\mathrm{~m}, \mathrm{br},-\mathrm{CH}_{3}\right)$. Anal. Calcd. for $\left[\left(\mathrm{C}_{68} \mathrm{H}_{74} \mathrm{~S}_{3}\right)_{1}+\left(\mathrm{C}_{48} \mathrm{H}_{50} \mathrm{~N}_{2} \mathrm{~S}_{3}\right)_{0.26}+\left(\mathrm{C}_{34} \mathrm{H}_{40} \mathrm{~N}_{2} \mathrm{~S}_{3}\right)_{0.34}\right]: \mathrm{C}$, 79.13; H, 7.26; N, 1.20; S, 11.02. Found: C, 77.47; H, 7.29; N, 1.23; S, 10.49. Weight-averaged $M_{\mathrm{w}}$ and PDI estimated from GPC are 65,000 and 2.50, respectively.

\section{Characterization}

${ }^{1} \mathrm{H}$ NMR spectra were recorded by Bruker Avance DRX 500 MHz. Gel permeation chromatographic (GPC) analysis was performed on a Lab Alliance RI2000 instrument (two column, MIXED-C and D from Polymer Laboratories) connected with one refractive index detector from Schambeck SFD Gmbh. All GPC analyses were performed on polymer/THF solution at a flow rate of $1 \mathrm{~mL} \min ^{-1}$ at $40{ }^{\circ} \mathrm{C}$ and calibrated with polystyrene standards.

Thermogravimetric analysis (TGA) and differential scanning calorimetry (DSC) measurements were performed under a nitrogen atmosphere at a heating rate of 20 and $10{ }^{\circ} \mathrm{C}$ $\min ^{-1}$ using a TA instrument (TGA-951 and DSC-910S), respectively. Atomic force microscopy (AFM) measurements were obtained with a NanoScope IIIa AFM (Digital Instruments, Santa Barbara, CA) at room temperature. Commercial silicon cantilevers (Nanosensors, Germany) with typical spring constants of 21-78 $\mathrm{N} \mathrm{m}^{-1}$ was used to operate the AFM in tapping mode. Images were taken continuously with the scan rate of $1.0 \mathrm{~Hz}$.

UV-vis absorption spectra of the spin-coated polymer films on quartz substrates were recorded on a Hitachi U-4100 spectrophotometer. For the thin film spectra, polymers were first dissolved in dichlorobenzene $\left(8 \mathrm{mg} \mathrm{mL}^{-1}\right)$ and filtered through $0.45 \mu \mathrm{m}$ pore size PTFE membrane syringe filters, spin-coated at a speed rate of $600 \mathrm{rpm}$ for $60 \mathrm{~s}$ onto quartz substrate. Cyclic voltammetry (CV) was performed with the use of a three-electrode cell in which ITO (polymer films area about $0.5 \times 0.7 \mathrm{~cm}^{2}$ ) was used as a working electrode.
A platinum wire was used as an auxiliary electrode. All cell potentials were taken with the use of a homemade $\mathrm{Ag} / \mathrm{AgCl}$, $\mathrm{KCl}$ (sat.) reference electrode. The energy levels of HOMO/ LUMO were determined from the onset oxidation $\left(E_{\text {onset }}^{\text {ox }}\right) /$ onset reduction $\left(E_{\text {onset }}^{\mathrm{red}}\right)$ and estimated on the basis of the reference energy level of ferrocence $(4.8 \mathrm{~V}$ below the vacuum level) according to the following equations: HOMO = $-\left[E_{\text {onset }}^{\text {ox }}-E_{1 / 2}^{\text {ferrocene }}+4.8\right](\mathrm{eV})$ and LUMO $=-\left[E_{\text {onset }}^{\text {red }}-\right.$ $\left.E_{1 / 2}^{\text {ferrocene }}+4.8\right](\mathrm{eV})$.

\section{Fabrication and Characterization of FETs}

Organic FETs were prepared from polymer thin films with a bottom-contact configuration on the heavily $n$-doped silicon wafers. A thermally grown $200 \mathrm{~nm} \mathrm{SiO} 2$ used as the gate dielectric with a capacitance of $17 \mathrm{nF} \mathrm{cm}{ }^{-2}$. The aluminum was used to create a common bottom-gate electrode. The source/drain regions were defined by a $100-\mathrm{nm}$ thick gold contact electrode through a regular shadow mask, and the channel length $(L)$ and width $(W)$ were $25 \mu \mathrm{m}$ and 500 or $100 \mu \mathrm{m}$, respectively. Afterward, the substrate was modified with octyltrichlorosilane (OTS) as silane coupling agents. Polymer solution with a concentration of $0.5 \mathrm{wt} \%$ in chlorobenzene was filtered through $0.20 \mu \mathrm{m}$ pore size PTFE membrane syringe filter. It was then spin-coated onto the silanized $\mathrm{SiO}_{2} / \mathrm{Si}$ substrate at a speed rate of $1000 \mathrm{rpm}$ for $60 \mathrm{~s}$ and cured at $60{ }^{\circ} \mathrm{C}$ overnight in vacuum. Output and transfer characteristics of the FET devices were measured using Keithley 4200 semiconductor parametric analyzer. All the procedures and electrical measurements were performed in ambient air.

\section{Fabrication and Characterization of Polymer Photovoltaic Cells and Near Infrared PDs}

All the bulk-heterojunction photovoltaic cells and PDs were prepared using the same preparation procedures and device fabrication procedure referring as following: the glassindium tin oxide (ITO) substrates (obtained from Sanyo, Japan ( 8 ohms per square) were first patterned by lithograph, then cleaned with detergent, and ultrasonicated in acetone and isopropyl alcohol, and subsequently dried on hot plate at $120{ }^{\circ} \mathrm{C}$ for $5 \mathrm{~min}$, and finally treated with oxygen plasma for 5 min. Poly(3,4-ethylenedioxy-thiophene):poly(styrene-sulfonate) (PEDOT:PSS, Baytron P VP AI4083) was passed through a $0.45-\mu \mathrm{m}$ filter before being deposited on ITO with a thickness around $30 \mathrm{~nm}$ by spin coating at $3000 \mathrm{rpm}$ in the air and dried at $140{ }^{\circ} \mathrm{C}$ for $1 \mathrm{~h}$ inside glove box. The thin film of the polymer $/ \mathrm{PC}_{71} \mathrm{BM}$ blends on the top of PEDOT:PSS layer was prepared by spin coating from dichlorobenzene solution. Subsequently, the device was completed by coating $30-\mathrm{nm}$ thickness of $\mathrm{Ca}$ and a $100-\mathrm{nm}$ thickness of $\mathrm{Al}$ under $<10^{-6}$ torr pressure, respectively. The active area of the device is $4 \mathrm{~mm}^{2}$. The external quantum efficiency (EQE) was measured by the spectral response measurement system (SR300,0ptosolar GMBH).

For the transient response measurement of PD, inorganic LED with $650 \mathrm{~nm}$ emission was driven by a function generator. The photocurrent of polymer PD is amplified by trans- 


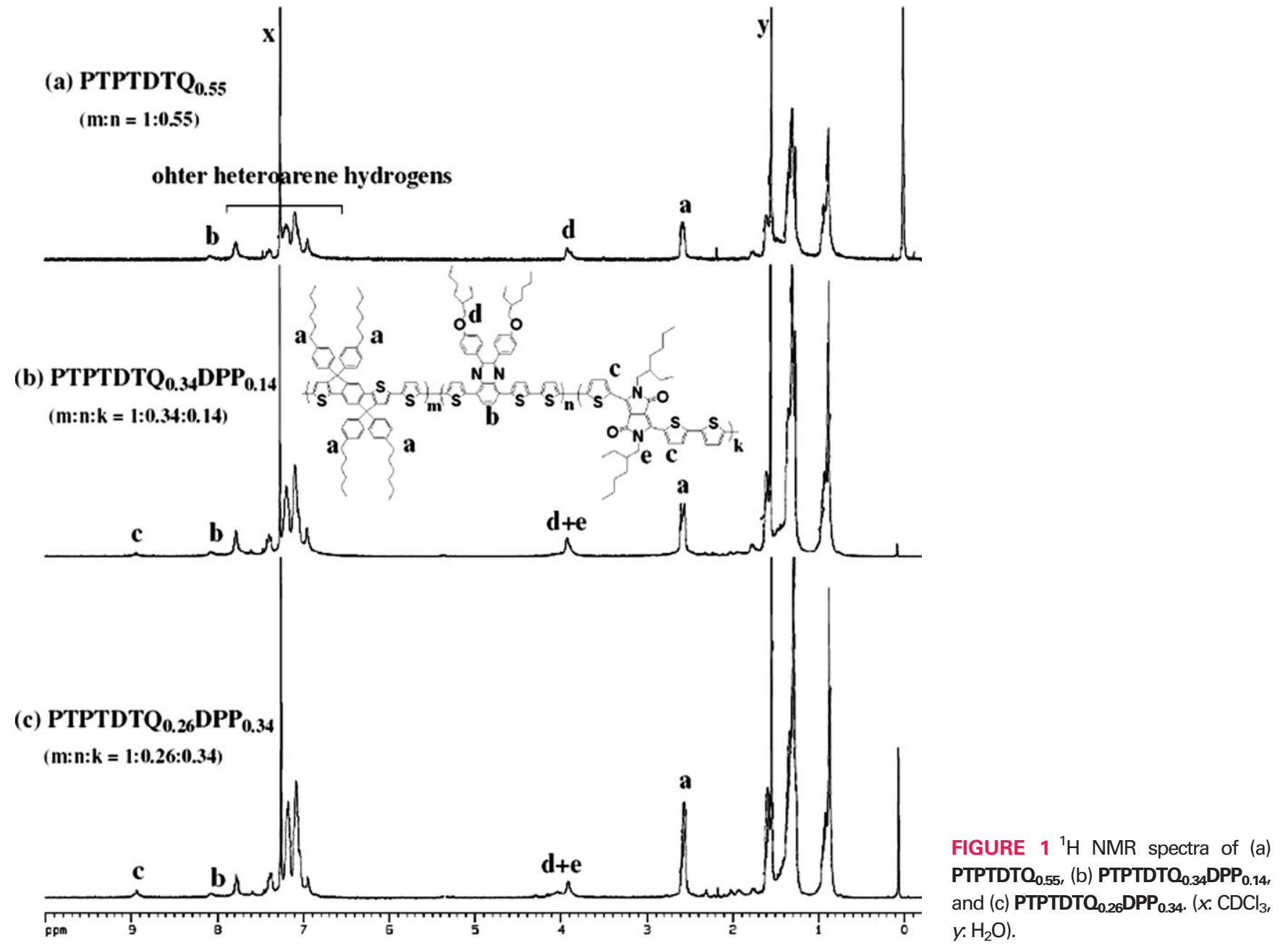

impedance amplifier (DHPCA-100, Femto-tech) and the output signal is read from digital oscilloscope.

\section{RESULTS AND DISCUSSION}

\section{Polymer Structure}

The chemical structures of the synthesized polymers are confirmed by ${ }^{1} \mathrm{H}$ NMR and elemental analysis. Figure 1 shows the ${ }^{1} \mathrm{H}$ NMR spectra of PTPTDTQ $\mathbf{0 . 5 5}_{\text {, }}$ PTPTDTQ $_{0_{34}}$ DPP $_{\mathbf{0 . 1 4}_{14}}$, and PTPTDTQ $_{\mathbf{0 . 2 6}_{6}} \mathbf{D P P}_{\mathbf{0 . 3 4}}$ in $\mathrm{CDCl}_{3}$. All spectra show the signal of the methylene group attached to the phenyl side group of TPT unit (peak a) at $2.57 \mathrm{ppm}^{15}$ Furthermore, the peaks in the range of $2.10-1.12\left(-\mathrm{CH}_{2}\right.$ and $-\mathrm{CH})$ and $1.12-0.7 \mathrm{ppm}\left(-\mathrm{CH}_{3}\right)$ are attributed to the hexyl group on TPT, the ethylhexyloxyphenyl group on DTQ and the ethylhexyl group in DPP. In the spectra of PTPTDTQ $\mathbf{0 . 3 4}_{\mathbf{0}} \mathbf{D P P}_{\mathbf{0 . 1 4}}$ and PTPTDTQ ${ }_{0.26}$ DPP $_{0.34}$ [Fig. 1(b,c)], the characteristic peaks at $\delta 8.10$ and $8.95 \mathrm{ppm}$ are assigned to the protons of the phenylene ring of quinoxaline unit and those of the thiophene ring of the DPP unit. These two characteristic peaks are used to estimate the ratios between DTQ and DPP units through the integral ratios and thus the copolymer compositions were determined. Moreover, the elemental analysis of studied poly- mers exhibits a moderate agreement with the estimated ratios of individual blocks from ${ }^{1} \mathrm{H}$ NMR results. The above structural characterization results indicate the successful synthesis of the TPT-based random copolymers. The weight-averaged $M_{\mathrm{w}}$ and PDI of the PTPTDTQ $_{0.55}$, PTPTDTQ $_{0.34} \mathbf{D P P}_{\mathbf{0 . 1 4}}$, and PTPTDTQ $\mathbf{0 . 2 6}_{\text {DPP }}$..34 $_{\text {are }}(76,000,1.97),(68,000,2.49)$, and $(65,000,2.50)$, respectively. The prepared copolymers were very soluble in common organic solvents. The high-molecular weight and good solubility of studied copolymers would be important for their device applications.

\section{Thermal Stability}

Figure 2 shows the TGA curves of the studied copolymers at the heating rate of $20{ }^{\circ} \mathrm{C} \mathrm{min}^{-1}$ under a nitrogen atmosphere. The thermal decomposition temperatures $\left(T_{\mathrm{d}}\right.$, 95 wt \% residue) of PTPTDTQ $_{0.55}$, PTPTDTQ $_{0.34}$ DPP $_{\mathbf{0 . 1 4}}$, and PTPTDTQ $_{\mathbf{0 . 2 6}} \mathbf{D P P}_{\mathbf{0 . 3 4}}$ under a nitrogen atmosphere are 455,468 , and $460{ }^{\circ} \mathrm{C}$, respectively; while their corresponding $T_{\mathrm{d}}$ under air are 449,378 , and $393{ }^{\circ} \mathrm{C}$ (see Supporting Information Figure S1). It indicates the good thermal stability and their potential application for TPT-based polymers. No clear thermal transition was observed from the DSC scan from 40 to $300{ }^{\circ} \mathrm{C}$, which was probably due to its rigid backbone. ${ }^{15}$ 


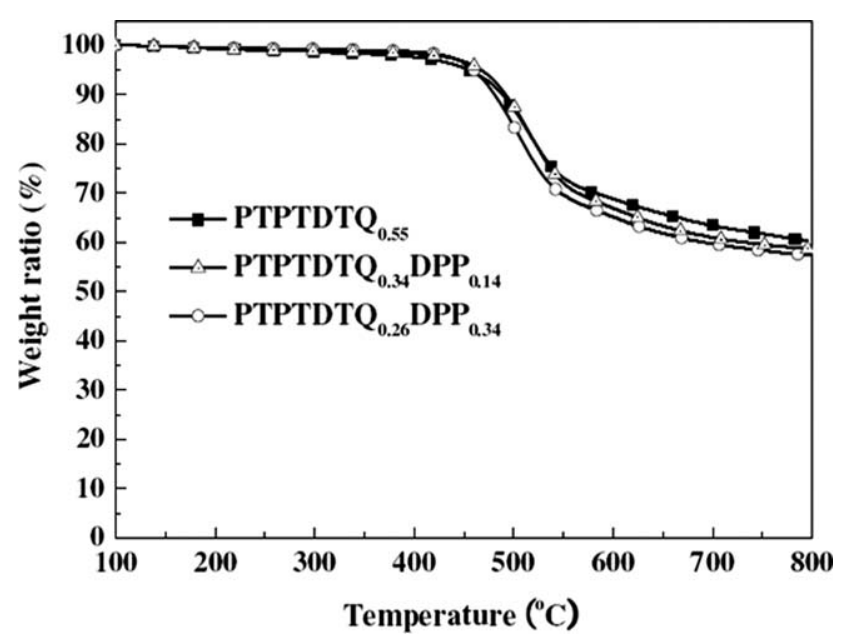

FIGURE 2 TGA curves of studied copolymers at the heating rate of $20^{\circ} \mathrm{C} \mathrm{min}^{-1}$ under nitrogen purging.

\section{Optical Properties}

The UV-vis absorption spectra of the studied copolymers in dilute $o$-dichlorobenzene and thin films are shown in Figure $3(a, b)$, respectively. The corresponding maximum absorption wavelengths $\left(\lambda_{\max }\right)$, optical band gaps $\left(E_{\mathrm{g}}^{\mathrm{opt}}\right)$, and absorption coefficients $(\alpha)$ are summarized in Table 1 . For PTPTDTQ $\mathbf{P}_{\mathbf{0 . 5 5}}$, the absorption band around 350-650 nm could be attributed to the combined contributions of TPT and DTQ blocks. With the incorporation of the DPP unit, the absorption spectra of PTPTDTQ $_{0.34}$ DPP $_{\mathbf{0 . 1 4}}$ and PTPTDTQ P.26 $_{\text {DPP }} \mathbf{P P}_{\mathbf{0 . 3 4}}$ exhibit two distinct peaks: the peak in the wavelength range of 350650 nm, similar to that of PTPTDTQ . $_{\mathbf{5 5}}$. Another peak in the wavelength range of $650-850 \mathrm{~nm}$ is due to the significant charge transfer between the TPT donor and the DPP acceptor. The $\lambda_{\max }$ of PTPTDTQ $\mathbf{0 . 5 5}_{5}$, PTPTDTQ $_{\mathbf{0 . 3 4}}$ DPP $_{\mathbf{0 . 1 4}}$, and PTPTDTQ $\mathbf{0 . 2 6}_{\mathbf{0}} \mathbf{D P P}_{\mathbf{0 . 3 4}}$ in dichlorobenzene solution are observed at 550, (547, 650, 686), and $(520,694) \mathrm{nm}$, respectively, while those of thin films are shown at 551, $(534,666)$, and $(515,713) \mathrm{nm}$. As more DPP units were incorporated into the copolymers, higher $\pi$-electron delocalization was occurred in the polymer chain and led to a significant red-shifting on the absorption spectra. ${ }^{55}$ The optical band gaps $\left(E_{\mathrm{g}}^{\mathrm{opt}}, \mathrm{eV}\right)$ estimated from the absorption edges of thin film spectra are in the following order: PTPTDTQ $\mathbf{0 . 5 5}_{\mathbf{0}}$
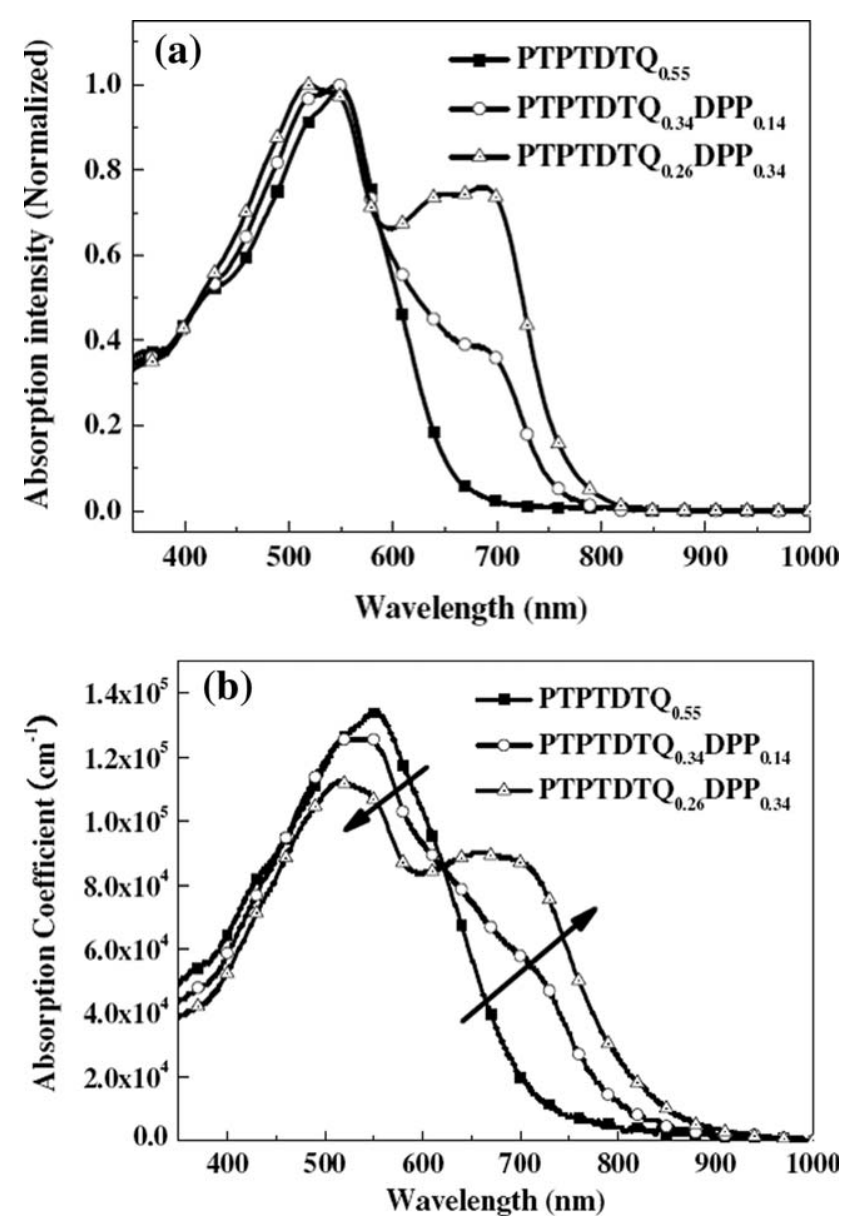

FIGURE 3 Optical absorption spectra of the studied copolymers in (a) dilute 1,2-dichlorobenzene solutions and (b) thin films on a quartz plate.

(1.74) > PTPTDTQ $_{0.34}$ DPP $_{\mathbf{0 . 1 4}}(1.56)>$ PTPTDTQ $_{0.26}$ DPP $_{\mathbf{0 . 3 4}}$ (1.48). By comparing with the absorption bands of the TPT homopolymer and its derivatives in our previous work, ${ }^{14}$ the studied copolymers exhibit lower band gaps and suggest the significant ICT in polymer chains.

On the other hand, the thin films of PTPTDTQ $\mathbf{P}_{\mathbf{0} 5 \mathbf{5}}(1.34 \times$ $10^{5} \mathrm{~cm}^{-1}$ at $\lambda_{\max }=$ ca. $\left.551 \mathrm{~nm}\right)$, PTPTDTQ $_{0.34}$ DPP $_{\mathbf{0 . 1 4}}$ $\left(1.26 \times 10^{5} \mathrm{~cm}^{-1}\right.$ at $\lambda_{\max }=$ ca. $\left.534 \mathrm{~nm}\right)$, and

TABLE 1 Molecular Weights, Thermal Properties, and Optical and Electrochemical Properties of the Studied TPT-Based Donor-Acceptor Random Copolymers

\begin{tabular}{|c|c|c|c|c|c|c|c|}
\hline \multirow[b]{3}{*}{ Polymer } & \multicolumn{4}{|c|}{ UV-Vis Absorption } & \multicolumn{3}{|c|}{ Cyclic Voltammetry } \\
\hline & \multirow{2}{*}{$\frac{\text { Solution (DCB) }}{\lambda_{\max }(\mathrm{nm})}$} & \multicolumn{2}{|c|}{ Film } & \multirow[b]{2}{*}{$E_{\mathrm{g}}^{\mathrm{opt}}(\mathrm{eV})$} & \multirow{2}{*}{$\frac{\mathrm{p} \text {-Doping }}{E_{\text {onset }}^{\text {ox }} / \mathrm{HOMO}(\mathrm{V}) /(\mathrm{eV})}$} & \multirow{2}{*}{$\frac{\mathrm{n} \text {-Doping }}{E_{\text {onset }}^{\text {red }} / \mathrm{LUMO}(\mathrm{V}) /(\mathrm{eV})}$} & \multirow[b]{2}{*}{$E_{\mathrm{g}}^{\mathrm{ec}}$} \\
\hline & & $\lambda_{\max }(\mathrm{nm})$ & $\alpha^{\mathrm{a}}$ & & & & \\
\hline PTPTDTQ $_{0.55}$ & 550 & 551 & 1.34 & 1.74 & $0.85 /-5.21$ & $-1.21 /-3.15$ & 2.06 \\
\hline PTPTDTO $_{0.34}$ DPP $_{0.14}$ & $547,650,686$ & 534,666 & 1.26 & 1.56 & $0.80 /-5.16$ & $-1.16 /-3.20$ & 1.96 \\
\hline PTPTDTO $_{0.26}$ DPP $_{0.34}$ & 520,694 & 515,713 & 1.13 & 1.48 & $0.76 /-5.12$ & $-0.94 /-3.42$ & 1.70 \\
\hline
\end{tabular}

a Absorption coefficient $(\alpha)$ of the solid thin film at its maximum intensity of absorption peak $\left(\times 10^{-5} \mathrm{~cm}^{-1}\right)$. 


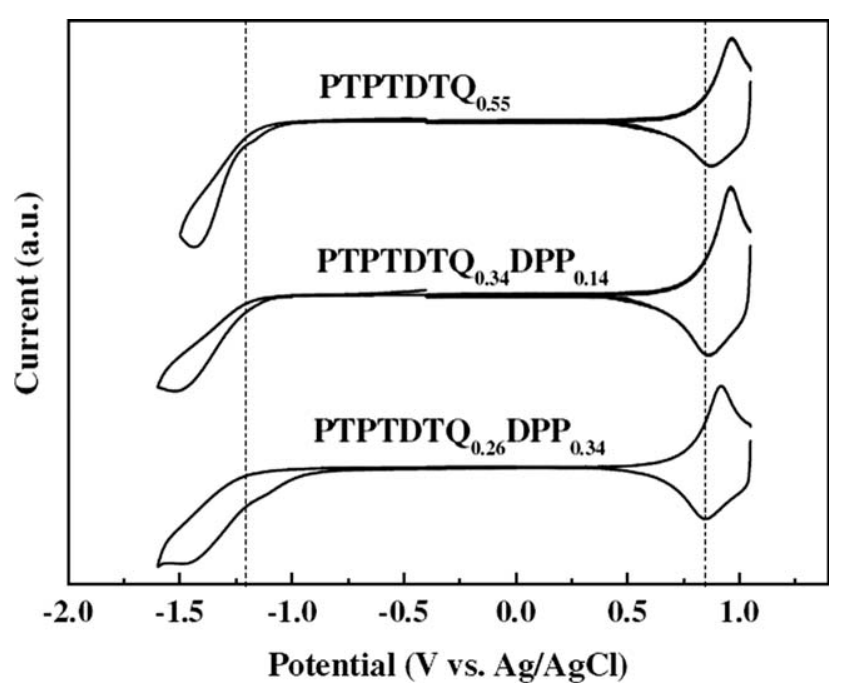

FIGURE 4 Cyclic voltammograms of studied copolymers thin film in an acetonitrile solution of $0.1 \mathrm{M}$ TBAP at a scan rate of $0.1 \mathrm{~V} \mathrm{~s}^{-1}$.

PTPTDTQ $_{\text {0.26 }}$ DPP $_{\mathbf{0 . 3 4}}\left(1.13 \times 10^{5} \mathrm{~cm}^{-1}\right.$ at $\lambda_{\text {max }}=$ ca. $515 \mathrm{~nm})$ exhibit high-absorption coefficients comparable with that of P3HT film $\left(1.9 \times 10^{5} \mathrm{~cm}^{-1}\right.$ at $\lambda_{\max }=\mathrm{ca}$. $552 \mathrm{~nm})$, as shown in Figure $3(\mathrm{~b})$. As the $E_{\mathrm{g}}^{\mathrm{opt}}$ of the prepared copolymers decreases, the absorption intensity around 350-650 nm increases while that of 650-850 nm decreases as the DPP composition was enhanced. Note that the optical band gap of PTPTDPP reported previously ${ }^{15}$ was lower than PTPTDTQ $_{\mathbf{0 . 2 6}}$ DPP $_{\mathbf{0 . 3 4}}$ in the present study, due to its stronger ICT. Thus, it is expected that the absorption spectrum of the copolymer could be further broadened at a higher DPP composition, which is important for near infrared device applications.

\section{Electrochemical Properties}

Figure 4 shows that the $\mathrm{CV}$ curves of the studied polymers using polymer films in acetonitrile at a potential scan rate of $100 \mathrm{mV} \mathrm{s}^{-1}$. The HOMO energy level, the LUMO energy level, and the electrochemical band gaps $\left(E_{\mathrm{g}}^{\mathrm{ec}}\right)$ of the polymers were calculated from onset oxidation potentials $\left(E_{\text {onset }}^{\text {ox }}\right)$ and onset reduction potentials ( $\left.E_{\text {onset }}^{\text {red }}\right)$, respectively, according to the following equations: $\mathrm{HOMO}=-\left[E_{\text {onset }}^{\text {ox }}-E_{1 / 2}^{\text {ferrocene }}+4.8\right]$ $\mathrm{V}$, LUMO $=-\left[E_{\text {onset }}^{\mathrm{red}}-E_{1 / 2}^{\text {ferrocene }}+4.8\right] \mathrm{V}$, where the potentials are referred to an $\mathrm{Ag} / \mathrm{AgCl}$ reference electrode. These results were summarized at Table 1. Apparently, these random copolymers exhibit reversible oxidative processes. The corresponding HOMO energy levels of PTPTDTQ $\mathbf{0 . 5 5}_{\text {. }}$, PTPTDTQ $\mathbf{Q}_{\mathbf{0 . 3 4}}$

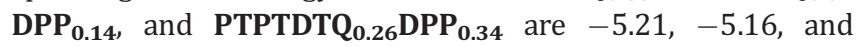
$-5.12 \mathrm{eV}$, respectively; their LUMO energy levels are -3.15 , -3.20 , and $-3.42 \mathrm{eV}$, respectively. The $E_{\mathrm{g}}^{\mathrm{ec}}$ values of our TPTbased copolymers are systematically larger than their values of $E_{\mathrm{g}}^{\mathrm{opt}}$, which is probably due to the exciton binding energy of conjugated polymers. ${ }^{41}$ As the ratio of DPP unit is increased

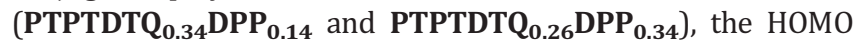
levels become higher and the LUMO levels become lower. When compared with PTPTQ $(-5.30 /-3.37 \mathrm{eV}),{ }^{15}$ the higher HOMO of PTPTDTQ $\mathbf{P . 5}_{\mathbf{5}}(-5.21 /-3.15 \mathrm{eV})$ could be attributed to the D-A-D ICT structure of DTQ while the electron-donating ethylhexyloxy-phenyl side chain on DTQ elevates the LUMO.

\section{Polymer FET Characteristics}

The charge transporting characteristics of the studied polymers were explored through the bottom contact FET devices and the relative results were summarized in Table 2. Figure 5 shows the FET output and transfer characteristics of the studied copolymer devices on the ODTS-modified $\mathrm{SiO}_{2}$. These polymers show typical $p$-channel characteristics [drain current $\left(I_{\mathrm{d}}\right)$ vs. drain voltage $\left(V_{\mathrm{d}}\right)$ at various gate voltages $\left.\left(V_{\mathrm{g}}\right)\right]$ when operate in the accumulation mode operation. In the saturation region $\left(V_{\mathrm{d}}>V_{\mathrm{g}}-V_{\mathrm{t}}\right), I_{\mathrm{d}}$ can be described by eq $1:^{38}$

$$
I_{\mathrm{d}}=\frac{W C_{\mathrm{o}} \mu_{\mathrm{h}}}{2 L}\left(V_{\mathrm{g}}-V_{\mathrm{t}}\right)^{2}
$$

where $\mu_{\mathrm{h}}$ is the hole mobility, $W$ is the channel width, $L$ is the channel length, and $C_{\mathrm{o}}$ is the capacitance of the gate insulator per unit area $\left(\mathrm{SiO}_{2}, 200 \mathrm{~nm}, C_{\mathrm{o}}=17 \mathrm{nF} \mathrm{cm}{ }^{-2}\right)$, respectively. The saturation region mobility of the studied polymers is calculated from the transfer characteristics of FET involving plotting $\left(I_{\mathrm{d}}\right)^{1 / 2}$ versus $V_{\mathrm{g}}$. The hole mobility of PTPTDTQ $_{0.55}$, PTPTDTQ $_{0.34}$ DPP $_{0.14}$, and PTPTDTQ ${ }_{0.26}$ DPP $_{0.34}$ is $2.2 \times 10^{-3}, 2.4 \times 10^{-3}$, and $4.7 \times 10^{-3} \mathrm{~cm}^{2} \mathrm{~V}^{-1} \mathrm{~s}^{-1}$, respectively, with their corresponding on-off ratios of $2.0 \times$ $10^{4}, 4.0 \times 10^{4}$, and $5.3 \times 10^{4}$. The hole mobility of these three TPT-based conjugated copolymers are comparable with other reported TPT derivatives fabricated with similar structures. ${ }^{15}$ It indicates that these poly(TPT) derivatives with a coplanar structure lead to high mobility of $>10^{-3}$ $\mathrm{cm}^{2} \mathrm{~V}^{-1} \mathrm{~s}^{-1} \cdot{ }^{15}$ As listed in Table 2, the FET mobility of the

TABLE 2 FET and Photovoltaic Characteristics of the Studied TPT-Based Donor-Acceptor Random Copolymers

\begin{tabular}{|c|c|c|c|c|c|c|}
\hline \multirow[b]{2}{*}{ Polymer } & \multicolumn{2}{|c|}{ FET-Pristine Polymer } & \multicolumn{4}{|c|}{ Photovoltaic Cell-Polymer/PC ${ }_{71} \mathrm{BM}(1: 3)$} \\
\hline & Mobility $\left(\mathrm{cm}^{2} \mathrm{~V}^{-1} \mathrm{~s}^{-1}\right)$ & On-Off (-) & $J_{\mathrm{sc}}\left(\mathrm{mA} \mathrm{cm}{ }^{-2}\right)$ & $V_{\mathrm{oc}}(\mathrm{V})$ & FF (\%) & $\operatorname{PCE}^{\mathrm{a}}(\%)$ \\
\hline PTPTDTQ $_{0.55}$ & $2.2 \times 10^{-3}$ & $4.0 \times 10^{4}$ & 10.40 & 0.740 & 0.484 & 3.71 \\
\hline PTPTDTO $_{0.34}$ DPP $_{0.14}$ & $2.4 \times 10^{-3}$ & $4.0 \times 10^{4}$ & 9.67 & 0.724 & 0.473 & 3.31 \\
\hline PTPTDTQ $_{0.26}$ DPP $_{0.34}$ & $4.7 \times 10^{-3}$ & $5.3 \times 10^{4}$ & 10.10 & 0.715 & 0.431 & 3.12 \\
\hline
\end{tabular}

a The average value of power conversion efficiency is calculated from 4 pixels in the device. 

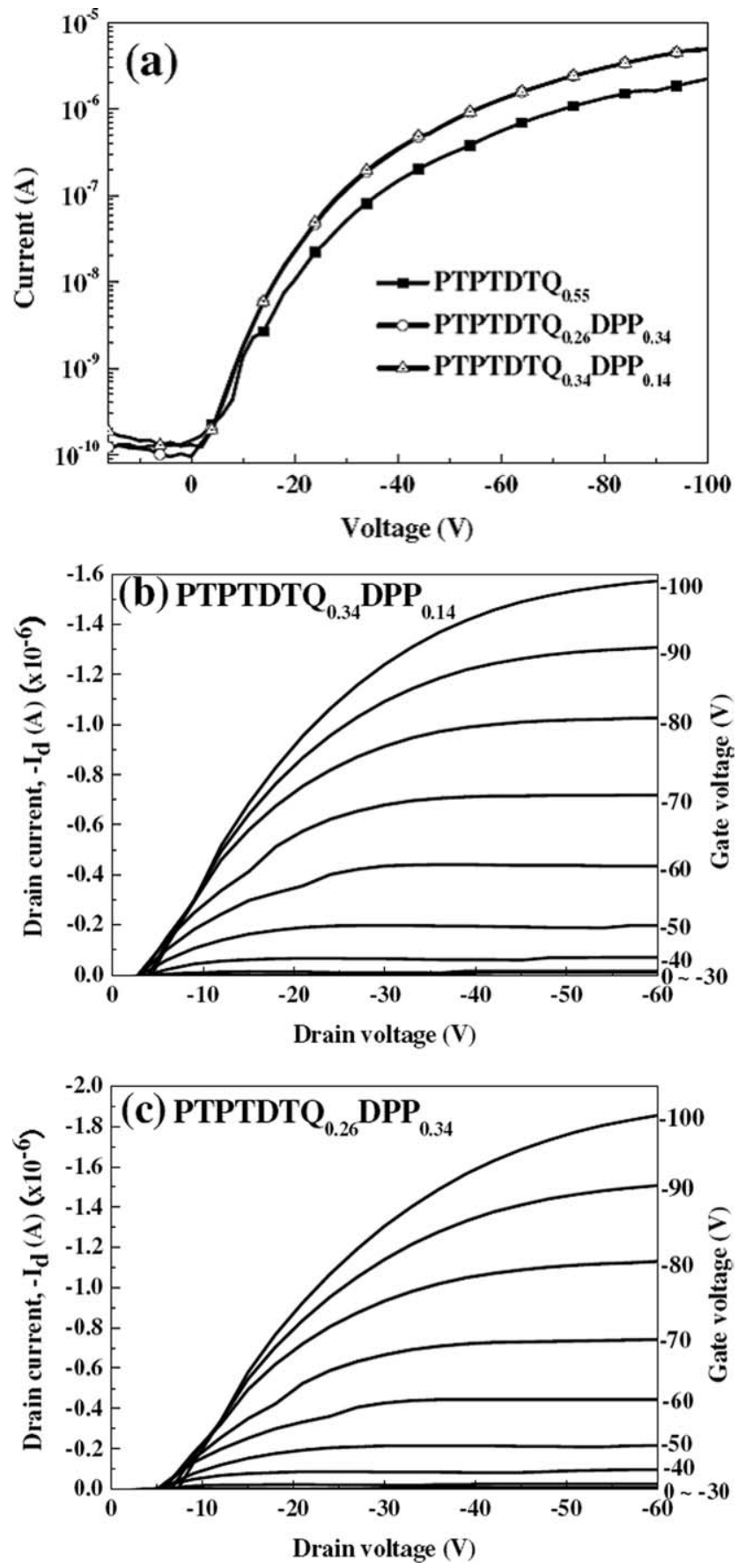

FIGURE 5 (a) Transfer characteristic of the polymer devices with an ODTS-modified surface and annealed at $100{ }^{\circ} \mathrm{C}$ for $30 \mathrm{~min}$, where $V_{\mathrm{ds}}=-100 \mathrm{~V}$. The output characteristics of (b) PTPTDTQ $_{0.34}$ DPP $_{0.14}$ and (c) PTPTDTQ ${ }_{0.26}$ DPP $_{0.34}$ based TFT devices.

studied polymer increases as the ratio of DPP raises. It might be arised from the following two factors: the raising HOMO level and the enhanced $\pi$-delocalization through the incorporation of the DPP units. The higher HOMO level could reduce the energy barrier between $\mathrm{Au}$ and active layer and then facilitate the charge injection. Furthermore, the incorporation of the DPP building block was reported to exhibit a high FET mobility for its excellent charge transporting ability. $^{55,56}$

\section{Polymer Photovoltaic Cell Characteristics}

According to previous reports, ${ }^{13}$ the bulk heterojunction solar cells were fabricated with a sandwich configuration of ITO/PEDOT:PSS/Polymer:PC ${ }_{71} \mathrm{BM} / \mathrm{Ca}(30 \mathrm{~nm}) / \mathrm{Al}(100 \mathrm{~nm})$. The active layers of studied polymers devices were fabricated without an annealing process. After encapsulation with UV-curing glue, the I-V characteristics were measured in air. The thickness of active layer can be controlled by changing the spin-coated rate and the concentration of active layer solution. The I-V characteristics of polymer solar cell prepared from the blends of polymer: $\mathrm{PC}_{71} \mathrm{BM}(1: 3, \mathrm{w} / \mathrm{w})$ were shown in Figure 6(a). The photovoltaic properties including opencircuit voltage $\left(V_{\mathrm{oc}}\right)$, short-circuit current $\left(U_{\mathrm{sc}}\right)$, fill factor $(\mathrm{FF})$, and power conversion efficiency (PCE) were summarized in Table 2. The PTPTDTQ $_{\mathbf{0 . 3 4}}$, PTPTDTQ $_{\mathbf{0 . 3 4}} \mathbf{D P P}_{\mathbf{0 . 1 4}}$, and
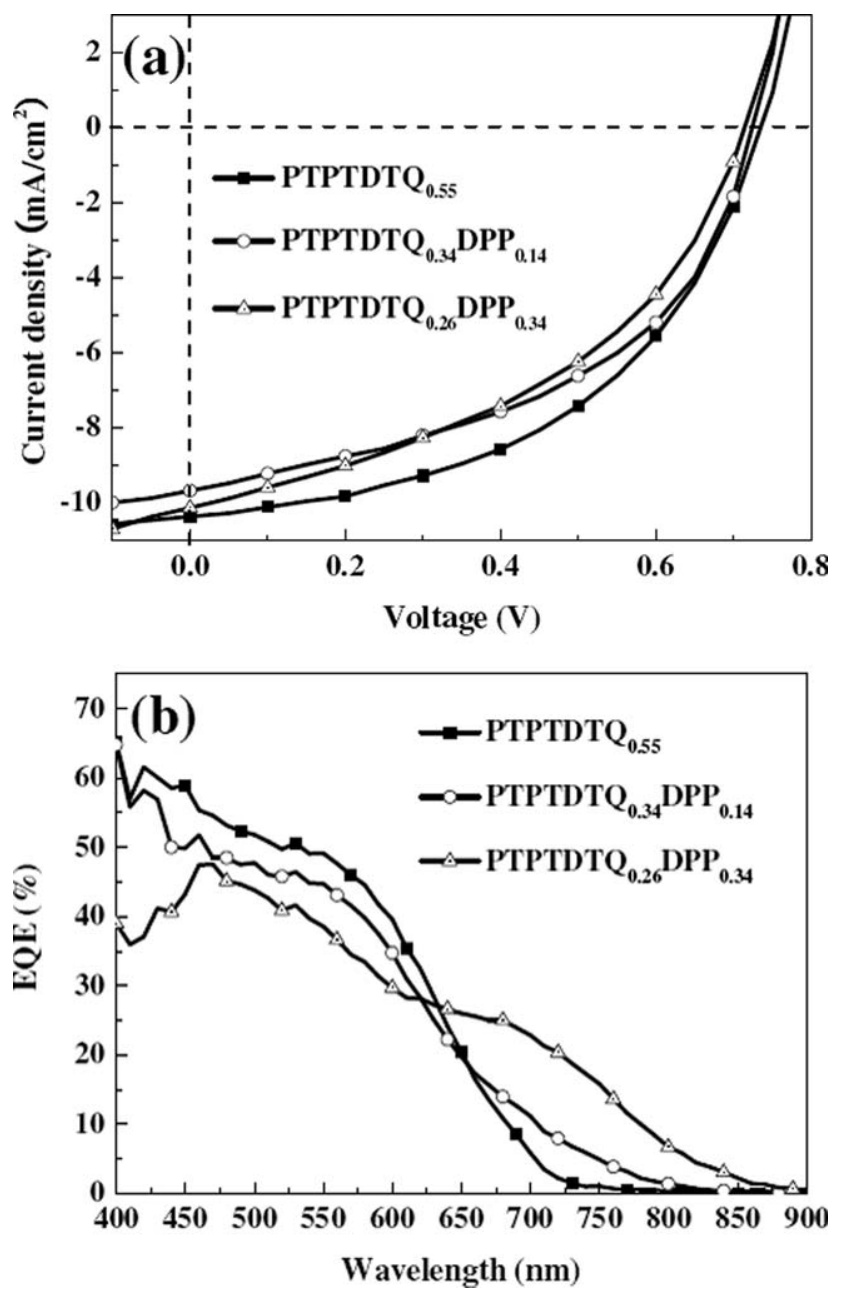

FIGURE 6 (a) Current density-potential characteristics of polymer solar cells with Polymer:PC ${ }_{71} \mathrm{BM}(1: 3, \mathrm{w} / \mathrm{w})$ under the illumination with AM $1.5 \mathrm{G}$ solar simulated light $\left(100 \mathrm{~mW} \mathrm{~cm}^{-2}\right)$. (b) The external quantum efficiency (EQE) spectra of devices fabricated with above device system. (Polymer: $\mathrm{P}_{71} \mathrm{CBM}=$ $1: 3)$. 


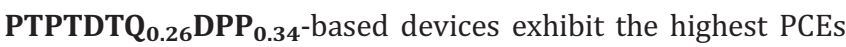
of $3.71,3.31$, and $3.12 \%$, respectively. The decreasing trend of PCE with the increasing DPP composition could be explained as follows. In general, the $V_{\text {oc }}$ value decreases with the increasing ratios of the DPP unit, which are consistent with their high-lying HOMO levels of PTPTDTQ $\mathbf{0 . 3 4}_{\mathbf{0}} \mathbf{D P P}_{\mathbf{0 . 1 4}}$ and PTPTDTQ $\mathbf{0 . 2 6}_{\text {. }} \mathbf{D P P}_{\mathbf{0 . 3 4}}$ when compared with that of

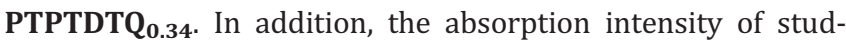
ied polymers in the visible region decreases but that in the infrared region enhances with the increasing the DPP composition. The EQE of the best performing devices [polymer: $\mathrm{PC}_{71} \mathrm{BM}=1: 3$, as shown in Fig. 6(a)] are depicted in Figure 6(b). The shape of the EQE curves of the devices is similar to their absorption spectra, indicating that all the absorption of the polymers contributed to the photovoltaic conversion. The integral area of the absorbance of

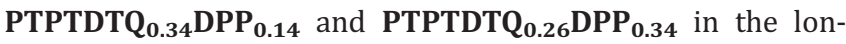
ger wavelength range from 650 to $850 \mathrm{~nm}$ is much higher than that of PTPTDTQ $\mathbf{Q}_{\mathbf{0 . 3 4}}$. However, these two copolymers exhibit a weaker absorbance in the visible region (400-650 $\mathrm{nm}$ ), leading the lower PCE of the devices than that of

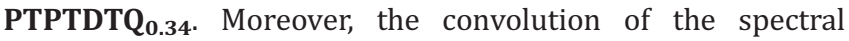
responses with the photon flux AM $1.5 \mathrm{G}$ spectra $(100 \mathrm{~mW}$ $\mathrm{cm}^{-2}$ ) provides for the $J_{\mathrm{sc}}$ values of $10.3,9.8$, and $10.0 \mathrm{~mA}$ $\mathrm{cm}^{-2}$ for the PTPTDTQ $\mathbf{0 . 3}_{\mathbf{3 4}}$, PTPTDTQ $_{\mathbf{0 . 3 4}} \mathbf{D P P}_{\mathbf{0 . 1 4}}$, and PTPTDTQ $_{\text {0.26 }}$ DPP $_{\mathbf{0 . 3 4}}$-based devices, respectively. It indicates that the absorption characteristics dominate their solar cell performances of the studied polymers. An $\sim 2 \%$ mismatch exists between the convolution and solar simulator data could be attributed the mismatch between the EQE light source and photon flux AM 1.5 G. ${ }^{15}$ The surface morphologies of our blended films (polymer: $\mathrm{PC}_{71} \mathrm{BM}=1: 3$ ) investigated by using tapping mode AFM shows a relatively small roughness for all three copolymers, as depicted in Supporting Information Figure S2. It indicates the morphological effect of the copolymers on the solar cell performance is insignificant. Although the broadened absorption spectra and the enhanced hole mobilities of PTPTDTQ $_{\mathbf{0 . 3 4}} \mathbf{D P P}_{\mathbf{0 . 1 4}}$ and PTPTDTQ $_{\mathbf{0 . 2 6}}$ DPP $_{\mathbf{0 . 3 4}}$ would benefit the PCE, the combination of the low-lying HOMO level and the better absorption spectral matching of PTPTDTQ $\mathbf{P}_{\mathbf{0 . 5 5}}$ render the best photovoltaic efficiency among the three copolymers.

\section{Polymer Near-Infrared PD}

Among the synthesized copolymers, PTPTDTQ $_{\mathbf{0 . 2 6}} \mathbf{D P P}_{\mathbf{0 . 3 4}}$ shows the lowest band gap (1.48 eV) and extends its absorption range up to near-infrared region; potential for the NIRPD application. When compared with inorganic semiconductors, the photoexcitation of organic semiconductors generates strong bound excitons rather than free charge carriers. To dissociate excitons efficiently, the donor/acceptor bulk heterojunction approach is typically used. ${ }^{43}$ On the basis of this concept, we fabricated our NIR-PD comprises of PTPTDTQ $_{\mathbf{0 . 2 6}}$ DPP $_{\mathbf{0 . 3 4}} / \mathrm{PC}_{71} \mathrm{BM}$ (1:3) device, forming interpenetrating donor/acceptor networks. Figure 7 (a) shows the EQE curve of the PTPTDTQ . $_{\mathbf{2}} \mathbf{D P P}_{\mathbf{0 . 3 4}}$-based PD. The EQE curves of PTPTDTQ $_{\mathbf{0 . 2 6}} \mathbf{D P P}_{\mathbf{0 . 3 4}} / \mathrm{PC}_{\mathbf{7 1}} \mathrm{BM}$ consistent with absorption spectra indicate that photons absorbed in IR
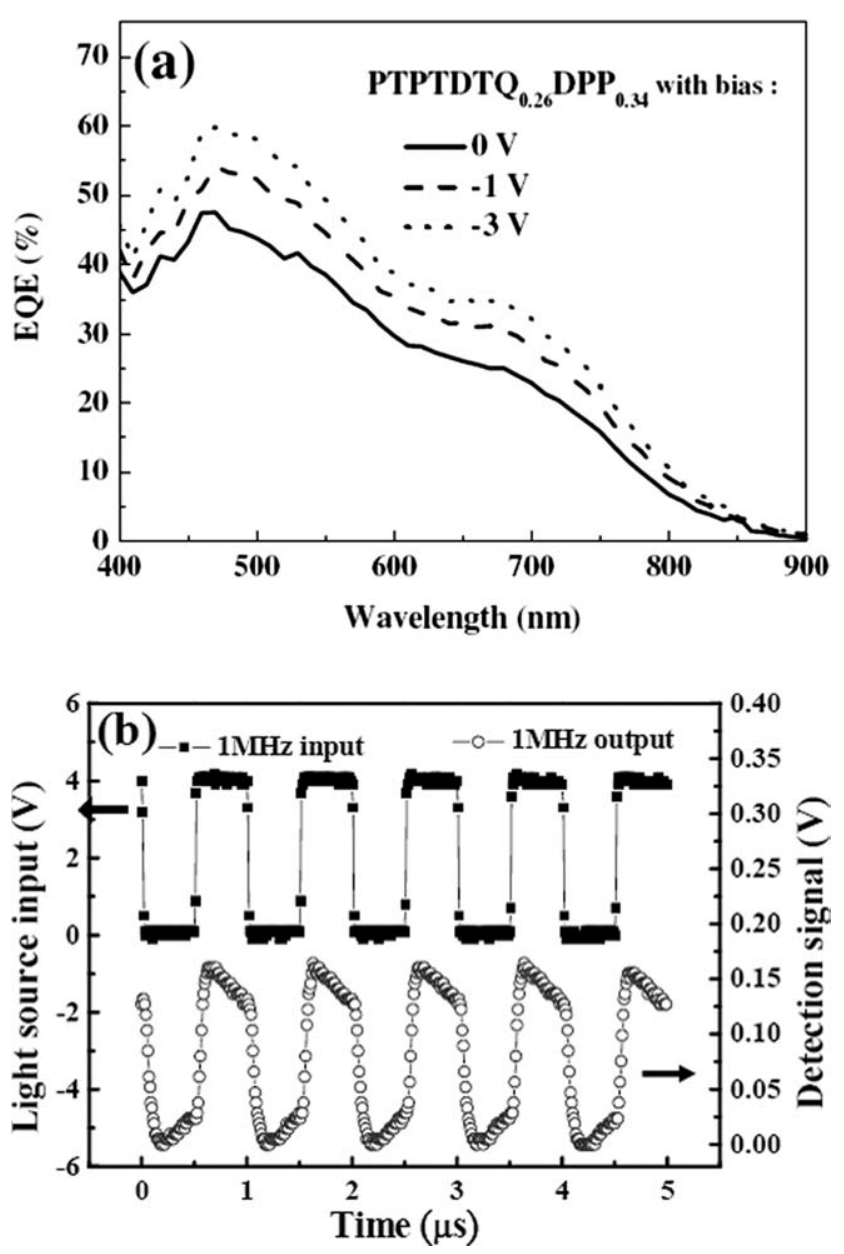

FIGURE 7 (a) The EQE spectrum of the near-infrared photodetector (PTPTDTQ $_{0.26}$ DPP $_{0.34} / \mathbf{P C}_{\mathbf{7 1}} \mathbf{B M}=1: 3$ ) application at reverse biases. (b) Transient response of the near-infrared photodetector (PTPTDTQ $_{0.26}$ DPP $_{0.34} / \mathrm{PC}_{71} \mathrm{BM}=\mathbf{1 : 3}$ ) under $1 \mathrm{MHz}$.

range by the active layer contributes to the photocurrent. The PTPTDTQ $\mathbf{0}_{\mathbf{0 . 2 6}} \mathbf{D P P}_{\mathbf{0 . 3 4}} / \mathrm{PC}_{71} \mathrm{BM}$ device exhibits $23 \%$ of $\mathrm{EQE}$ at $700 \mathrm{~nm}$ and increases by a factor of 1.4 to $32 \%$ at $-3 \mathrm{~V}$, which is probably attributes due to the enhanced charge collection under reverse bias. The device exhibits infrared response up to $850 \mathrm{~nm}$, which is much longer than that in P3HT:PCBM $(650 \mathrm{~nm}){ }^{44}$

In addition to the sensitivity, the fast response is strongly desired for the high-speed scanning in the large area PD array. The frame rate of the PD array is limited by the speed of PD. Moreover, the high-speed PD enables noise removal by the AC mode operation. For the frequency response measurement, the light source is a $650 \mathrm{~nm}$ inorganic LED operated at $4 \mathrm{~V}$ and modulated at $1 \mathrm{MHz}$. The polymer PD is operated at the reverse bias of $-3 \mathrm{~V}$. Figure 7 (b) shows the transient response of a PD under $650 \mathrm{~nm}$ the inorganic LED illumination. The carrier mobility of $1 \mathrm{MHz}$ operation could be estimated about $10^{-4} \mathrm{~cm}^{2} \mathrm{~V}^{-1} \mathrm{~s}^{-1}$ by calculating the average drift velocity under the assumption of the uniform electric field in the active layer. The high EQE spectral response and fast-speed response of PTPTDTQ $_{\mathbf{0 . 2 6}} \mathbf{D P P}_{\mathbf{0 . 3 4}} / \mathrm{PC}_{71} \mathrm{BM}$ 
based PD device suggests their potential applications of TPT-based low band gap polymers.

\section{CONCLUSIONS}

Three new TPT-based random copolymers, PTPTDTQ $_{\mathbf{0 . 5 5}}$, PTPTDTQ $_{0_{0.34}}$ DPP $_{0.14}$, and PTPTDTQ $_{0.26}$ DPP $_{0.34}$ were successfully synthesized by palladium(0)-catalyzed Stille coupling reaction. The absorption spectra and energy level of resulting copolymers could be easily tuned by changing the ratios of DTQ and DPP blocks. The incorporation of the DPP unit incorporated into polymer main chain significantly increased the near infrared absorption, lowered the band gap, and enhanced the carrier mobility. The photovoltaic device based on PTPTDTQ $_{0.55}: \mathrm{PC}_{71} \mathrm{BM}(1: 3, \mathrm{w} / \mathrm{w})$ bulk heterojunction shows the best PCE of $3.71 \%$ under the illumination of AM 1.5G (100 $\mathrm{mW} \mathrm{cm}^{-2}$ ). In addition, the TPT-based NIR PD characteristics exhibited the high EQE spectral response and fast-speed response. Our experimental results suggested that the TPT-based D-A-D conjugated copolymers could exhibit versatile optoelectronic applications.

This work was supported by National Science Council, Ministry of Economics Affairs, and the excellent project of National Taiwan University.

\section{REFERENCES AND NOTES}

1 van Mullekom, H. A. M.; Vekemans, J.; Havinga, E. E.; Meijer, E. W. Mater Sci Eng 2001, 32, 1-40.

2 Tsai, F. C.; Chang, C. C.; Liu, C. L.; Chen, W. C.; Jenekhe, S. A. Macromolecules 2005, 38, 1958-1966.

3 Ego, C.; Marsitzky, D.; Becker, S.; Zhang, J. Y.; Grimsdale, A. C.; Mullen, K.; MacKenzie, J. D.; Silva, C.; Friend, R. H. J Am Chem Soc 2003, 125, 437-443.

4 Liu, J.; Guo, X.; Bu, L. J.; Xie, Z. Y.; Cheng, Y. X.; Geng, Y. H.; Wang, L. X.; Jing, X. B.; Wang, F. S. Adv Funct Mater 2007, 17, 1917-1925.

5 Wu, W. C.; Liu, C. L.; Chen, W. C. Polymer 2006, 47, 527-538.

6 Yang, R. Q.; Tian, R. Y.; Yan, J. G.; Zhang, Y.; Yang, J.; Hou, Q.; Yang, W.; Zhang, C.; Cao, Y. Macromolecules 2005, 38, 244-253.

7 Lin, Y.; Chen, Z. K.; Ye, T. L.; Dai, Y. F.; Ma, D. G.; Ma, Z.; Liu, Q. D.; Chen, Y. J Polym Sci Part A: Polym Chem 2010, 48, 292-301.

8 Tang, W. H.; Lin, T. T.; Ke, L.; Chen, Z. K. J Polym Sci Part A: Polym Chem 2008, 46, 7725-7738.

9 Tang, W. H.; Ke, L.; Tan, L. W.; Lin, T. T.; Kietzke, T.; Chen, Z. K. Macromolecules 2007, 40, 6164-6171.

10 Dennler, G.; Scharber, M. C.; Ameri, T.; Denk, P.; Forberich, K.; Waldauf, C.; Brabec, C. J. Adv Mater 2008, 20, 579-583.

11 Scharber, M. C.; Wuhlbacher, D.; Koppe, M.; Denk, P.; Waldauf, C.; Heeger, A. J.; Brabec, C. L. Adv Mater 2006, 18, 789-794.
12 Coakley, K. M.; McGehee, M. D. Chem Mater 2004, 16, 4533-4542.

13 Chen, C. P.; Chan, S. H.; Chao, T. C.; Ting, C.; Ko, B. T. J Am Chem Soc 2008, 130, 12828-12833.

14 Chan, S. H.; Chen, C. P.; Chao, T. C.; Ting, C.; Lin, C. S.; Ko, B. T. Macromolecules 2008, 41, 5519-5526.

15 Yu, C. Y.; Chen, C. P.; Chan, S. H.; Hwang, G. W.; Ting, C. Chem Mater 2009, 21, 3262-3269.

16 Lu, J. P.; Liang, F. S.; Drolet, N.; Ding, J. F.; Tao, Y.; Movileanu, R. Chem Commun 2008, 5315-5317.

17 Tsai, J. H.; Chueh, C. C.; Lai, M. H.; Wang, C. F.; Chen, W. C.; Ko, B. T.; Ting, C. Macromolecules 2009, 42, 1897-1905.

18 Lai, M. H.; Chueh, C. C.; Chen, W. C.; Wu, J. L.; Chen, F. C. J Polym Sci Part A: Polym Chem 2009, 47, 973-985.

19 Li, G.; Shrotriya, V.; Huang, J. S.; Yao, Y.; Moriarty, T.; Emery, K.; Yang, Y. Nat Mater 2005, 4, 864-868.

20 Kim, Y.; Cook, S.; Tuladhar, S. M.; Choulis, S. A.; Nelson, J.; Durrant, J. R.; Bradley, D. D. C.; Giles, M.; McCulloch, I.; Ha, C. S.; Ree, M. Nat Mater 2006, 5, 197-203.

21 Peet, J.; Kim, J. Y.; Coates, N. E.; Ma, W. L.; Moses, D.; Heeger, A. J.; Bazan, G. C. Nat Mater 2007, 6, 497-500.

22 Wong, W. Y.; Wang, X. Z.; He, Z.; Djurisic, A. B.; Yip, C. T.; Cheung, K. Y.; Wang, H.; Mak, C. S. K.; Chan, W. K. Nat Mater 2007, 6, 521-527.

23 Gadisa, A.; Mammo, W.; Andersson, L. M.; Admassie, S.; Zhang, F.; Andersson, M. R.; Inganäs, O. Adv Funct Mater 2007, 17, 3836-3842.

24 Li, Y. F.; Zou, Y. P. Adv Mater 2008, 20, 2952-2958.

25 He, Y. J.; Wu, W. P.; Liu, Y. Q.; Li, Y. F. J Polym Sci Part A: Polym Chem 2009, 47, 5304-5312.

26 Li, W. W.; Du, C.; Li, F. H.; Zhou, Y.; Fahlman, M.; Bo, Z. S.; Zhang, F. L. Chem Mater 2009, 21, 5327-5334.

27 Zhang, S. M.; Guo, Y. L.; Fan, H. J.; Liu, Y.; Chen, H. Y.; Yang, G. W.; Zhan, X. W.; Liu, Y. Q.; Li, Y. F.; Yang, Y. J Polym Sci Part A: Polym Chem 2009, 47, 5498-5508.

28 Soci, C.; Hwang, I. W.; Moses, D.; Zhu, Z.; Waller, D.; Gaudiana, R.; Brabec, C. J.; Heeger, A. J. Adv Funct Mater 2007, 17, 632-636.

29 Moulé, A. J.; Tsami, A.; Buennagel, T. W.; Forster, M.; Kronenberg, N. M.; Scharber, M.; Koppe, M.; Morana, M.; Brabec, C. J.; Meerholz, K.; Scherf, U. Chem Mater 2008, 20, 4045-4050.

30 Chang, Y. T.; Hsu, S. L.; Chen, G. Y.; Su, M. H.; Singh, T. A.; Diau, E. W. G.; Wei, K. H. Adv Funct Mater 2008, 18, 2356-2365.

31 Baek, N. S.; Hau, S. K.; Yip, H. L.; Acton, O.; Chen, K. S.; Jen, A. K. Y. Chem Mater 2008, 20, 5734-5736.

32 Okamoto, T.; Jiang, Y.; Qu, F.; Mayer, A. C.; Parmer, J. E.; McGehee, M. D.; Bao, Z. N. Macromolecules 2008, 41, 6977-6980.

33 Li, K. C.; Hsu, Y. C.; Lin, J. T.; Yang, C. C.; Wei, K. H.; Lin, H. C. J Polym Sci Part A: Polym Chem 2009, 47, 2073-2092.

34 Chua, L. L.; Zaumseil, J.; Chang, J. F.; Ou, E. C. W.; Ho, P. K. H.; Sirringhaus, H.; Friend, R. H. Nature 2005, 434, 194-199. 
35 Chen, M. X.; Crispin, X.; Perzon, E.; Andersson, M. R.; Pullerits, T.; Andersson, M.; Inganäs, O.; Berggren, M. Appl Phys Lett 2005, 87, 252105-252107.

36 Lee, W. Y.; Cheng, K. F.; Wang, T. F.; Chueh, C. C.; Chen, W. C.; Tuan, C. S.; Lin, J. L. Macromol Chem Phys 2007, 208, 1919-1927.

37 Cheng, K. F.; Liu, C. L.; Chen, W. C. J Polym Sci Part A: Polym Chem 2007, 45, 5872-5883.

38 Liu, C. L.; Tsai, J. H.; Lee, W. Y.; Chen, W. C.; Jenekhe, S. A. Macromolecules 2008, 41, 6952-6959.

39 Champion, R. D.; Cheng, K. F.; Pai, C. L.; Chen, W. C.; Jenekhe, S. A. Macromol Rapid Commun 2005, 26, 1835-1840.

40 Babel, A.; Zhu, Y.; Cheng, K. F.; Chen, W. C.; Jenekhe, S. A. Adv Funct Mater 2007, 17, 2542-2549.

41 Zhu, Y.; Champion, R. D.; Jenekhe, S. A. Macromolecules 2006, 39, 8712-8719.

42 Zhou, E. J.; Tan, Z.; Yang, Y.; Huo, L. J.; Zou, Y. P.; Yang, C. H.; Li, Y. F. Macromolecules 2007, 40, 1831-1837.

43 Yao, Y.; Liang, Y. Y.; Shrotriya, V.; Xiao, S. Q.; Yu, L. P.; Yang, Y. Adv Mater 2007, 19, 3979-3983.

44 Chen, E. C.; Tseng, S. R.; Ju, J. H.; Yang, C. M.; Meng, H. F.; Horng, S. F.; Shu, C. F. Appl Phys Lett 2008, 93, 063304-063306.

45 Wan, M. X.; Wu, W. P.; Sang, G. Y.; Zou, Y. P.; Liu, Y. Q.; Li, Y. F. J Polym Sci Part A: Polym Chem 2009, 47, 4028-4036.
46 Peng, Q.; Xu, J.; Zheng, W. X. J Polym Sci Part A: Polym Chem 2009, 47, 3399-3408.

47 Lee, Y.; Fukukawa, K. I.; Bang, J.; Hawker, C. J.; Kim, J. K. J Polym Sci Part A: Polym Chem 2008, 46, 8200-8205.

48 Thompson, B. C.; Kim, Y. G.; McCarley, T. D.; Reynolds, J. R. J Am Chem Soc 2006, 128, 12714-12725.

49 Yasuda, T.; Imase, T.; Yamamoto, T. Macromolecules 2005, $38,7378-7385$

50 Blouin, N.; Michaud, A.; Leclerc, M. Adv Mater 2007, 19, 2295-2300.

51 Blouin, N.; Michaud, A.; Gendron, D.; Wakim, S.; Blair, E.; Neagu-Plesu, R.; Belletete, M.; Durocher, G.; Tao, Y.; Leclerc, M. J Am Chem Soc 2008, 130, 732-742.

52 Oin, R. P.; Li, W. W.; Li, C. H.; Du, C.; Veit, C.; Schleiermacher, H. F.; Andersson, M.; Bo, Z. S.; Liu, Z. P.; Inganas, O.; Wuerfel, U.; Zhang, F. L. J Am Chem Soc 2009, 131, 14612-14613.

53 Koyuncu, S.; Zafer, C.; Koyuncu, F. B.; Aydin, B.; Can, M.; Sefer, E.; Ozdemir, E.; Icli, S. J Polym Sci Part A: Polym Chem 2009, 47, 6280-6291.

54 Kitamura, C.; Tanaka, S.; Yamashita, Y. Chem Mater 1996, 8, 570-578.

55 Burgi, L.; Turbiez, M.; Pfeiffer, R.; Bienewald, F.; Kirner, H. J.; Winnewisser, C. Adv Mater 2008, 20, 2217-2224.

56 Wienk, M. M.; Turbiez, M.; Gilot, J.; Janssen, R. A. J. Adv Mater 2008, 20, 2556-2560. 